\title{
The (Re)Turn of the Prophets: Prophetic Portrait as a Paradigm of Critique for Post-Secular Society ${ }^{1}$
}

\author{
Prof. Ben Carlo N. ATIM \\ Saint Paul Seminary San Beda College \\ PHILIPPINES \\ ben_carlo85@yahoo.com.ph
}

\begin{abstract}
The paper has two main objectives: (a) it aims to present that a portrait of a prophet is a doable paradigm for critiquing the socio-political, economic, and cultural condition of the post-secular society and (b) attempts to find the prophets in our age. By understanding the life of the prophets, one can find robust insights that will guide us to clearly establish relations and connections between the past and the present real situation using a historicocritical and sociological approach.
\end{abstract}

Keywords: post-secular society, prophetic paradigm, critique, prophetic portrait.

\section{INTRODUCTION}

The paper has two main objectives: (a) it aims to present that a portrait of a prophet is a doable paradigm for critiquing the socio-political, economic, and cultural condition of the post-secular society and (b) attempts to find the prophets in our age. By understanding the life of the prophets, one can find robust insights that will guide us to clearly establish relations and connections between the past and the present real situation using a historicocritical and sociological approach. As we are all aware, the biblical prophets exemplify moral greatness, overwhelming courage, indisputable will power, strong conviction, and enormous spiritual influence in articulating their visions and oracles received from God. It is shown in their character the remarkable power of conceiving a unique linguistic attitude as well as the ability to penetrate the very being of their audience. Their acute and blatant criticisms against the oppressors and indifferent individuals are necessary to bring the issues and problems of their time within the fore of consciousness. These same characteristics demand our attention today because these are integral in social transformation. There is a call for "prophetic integration" of ideals, roles, and principles rooted in the values of the biblical prophets to be assimilated in our daily practices. Our society today, seen from the perspective of enlightened avant-garde discerners like the prophets of old, is characterized as frenetic, decentralized, dysfunctional, and disintegrated whose structures and functions are obviously degenerating and retarding. Hence, this paper tries to show that the portrait of a

[1] By critique I mean a reflective and systematic inquiry on the subject to be examined. This is akin to the Hegelian and Kantian concept of critique. The post-secular society is taken from Jurgen Habermas who claimed that the society has already entered another period where secularization no longer becomes viable instead the return of religious form of reasoning and its influence in the public sphere have been overlooked by secular-political theorists. Peter Berger calls this new phenomenon "desecularization of the society". 
prophet will help us see, examine, and critique using the "prophetic lens" the present condition of our society.

In order to achieve this, the paper will articulate on the following essential points: first, the idea that the exemplary life of the prophets can be an inspiration to all of us today who are situated in a kind of society not so different from theirs; secondly, the themes common to almost all of the major and minor prophets especially Amos, Jeremiah, Hosea, Isaiah, and Ezekiel have to do with their outright denunciation of social injustice and moral decay caused by the perversion of humanity towards God's divine love and compassion; thirdly, the visions, exhortations, and oracles by the Hebrew prophets transcend the time of their proclamation because even today the content of their messages describes the state of the current society; fourthly, the root of social illness and human decadence can still be attributed to the "royal kings"2 or the select few. Fifthly, although the Hebrew prophets are limited in a sense that they spoke in their time, but the characteristics and the role they played remain essential in examining the present situation. By looking at the present, those characteristics are still evident and being practiced by daring individuals. Lastly, drawing from the understanding of the essential attributes of the Hebrew prophets, the paper tries to locate the prophetic character within the present socio-political and cultural sphere. Hence, it will only endeavor to examine and interpret the attributes of the prophets - a portrait, and their message sociologically as we try to relate them to the present condition. The caveat, however, is to understand the entire corpus as a discourse intended to articulate and make it more apparent in our consciousness also the role of God in human history. For the prophets, God is always active in history. The dubious faith in human rationality has caused rampant inequalities, perversions, failures, injustices and exploitation. ${ }^{3}$ This is due to total neglect of the divine presence of God working in history and an outright denial of his divine act in human struggle. In what follows, I intend to offer a reflective discourse on the issues the paper aims to articulate.

\section{PROPHET: DEFINITION, MEANING AND UNDERSTANDING}

There is a grave misrepresentation and misconception of the prophets from the point of view of an ordinary Bible reader. To an ordinary believer, the prophets are known to be seers, diviners, or clairvoyants who are capable of "seeing" the future by performing rituals similar to animistic practices by the pagans. ${ }^{4}$ These prophets are also compared to some sort of fortune-teller who cast their predictions through the use of instruments believed to be reliable in knowing the future..$^{5}$ Although the Bible contains several accounts regarding this

[2]Taken metaphorically, the "royal kings" of today have undergone a quite radical and subtle transformation morphing into another form or personality no longer a single individual but can be an institution or any form of entity whose character are similar to that of the earthly kings of old.

[3]Science for instance affirms the authority of reason over faith and sees everything in the light of reason alone, dismissing the instrumentality and function of faith in making the world a better place. However, despite this science unconsciously creates instruments hostile to human flourishing and instead allows wider space for dangerous activity.

[4]Animism has been considered as crude religious practice, which uses living or non-living things as object of worship. In animistic culture those who perform the rituals are called shamans or diviners. In the Philippines, they are called babylans or catalonans. They take charge of the religious affairs and possess full authority on religious matters. They serve as advisors of the chieftain and the sole source of predictions.

[5]Those who are categorized as fortune-teller used various methods in interpreting the future such as cards, stars, and horoscopic symbols. 
perception about the prophets, ${ }^{6}$ the Hebrew Major Prophets essentially laid the ground for a quite different view, which clears our understanding of them. ${ }^{7}$ Despite this, it remains in the consciousness of the people the parasitic view about prophets who have the capacity to perform rituals or doing other forms of practices in uncovering the divine will. The definitional meaning of the word derived from Greek language more or less brought this about. The etymology of the English word is derived from the Greek preposition (pro) and a noun (phetes) that means an agent. The preposition pro has three main senses namely, temporal, spatial, and representative. ${ }^{8}$ According to Privost, the Greek preposition has been favourably taken by the Christian tradition in its first sense (temporal), which is equivalent to the term 'predict'. This gives us an idea that by its etymological definition, we have an understanding of a prophet as an individual "who spoke in advance, who predicted events to come, and, in a quiet way, the coming of the Messiah and the different aspects of his mission." Hence, due to short of knowledge, people crudely understood the prophets as those professional futurologists. To avoid this erroneous understanding, the Hebrew word for prophet must be invoked. In Hebrew, a prophet is someone who is called or perhaps someone who announces or proclaims the message of God. ${ }^{10}$ The Hebraic view avoids our tendency to misconstrue the biblical prophets. These prophets such as Amos, Jeremiah, Hosea, Isaiah and the like are neither diviners nor seers as the Hebraic definition reveals. They do not perform divination or any kind of similar character the Bible strongly condemns. ${ }^{11}$ Rather the Hebrew prophets are individuals who are called by God to be his messenger and spokesperson of his message. There is no technique in receiving God's message. The message God wanted to convey is transmitted in a profoundest and inexplicable manner by which the prophet himself cannot fully understand. This means that the use of external instrument is totally unnecessary to the delivery of the message of God, let alone words as pronounced by the sacred mouths from a divine source suffice. Needless to say, prophets have direct contact with the divine, "either when they are possessed by the divine or when they supernaturally transcend the human world to enter the divine realm." 12 However, this direct contact should not be understood literally since such entails logical problems. By direct contact we mean that prophets receive their visions, perform oracles, and provide exhortations by serious discernment on the issues or problems at hand while recognizing that in the process of discernment the divine presence is invoked and everpresent. For Ratzinger, the "essential element of the prophet...is to tell the truth on the strength of his contact with God; the truth for today which also, naturally, sheds light on the future." 13 In this manner, the utterances of the prophets are, though words are flowing from

[6] In the Old Testament accounts on divination and other forms of prophesying can be found in the earlier books (deuteronomistic tradition) where the known prophets are those who serve the kings and predict the future mostly favourable to the plans of the kings.

[7] Although earlier than these prophets, the books of Kings and Judges already provide template for distinction. A classic example is Micah in the book of 1 Kings. The writer distinguishes the true from false prophets.

[8] Privost, Jean-Pierre, How to Read the Prophets. Translated Bowden, J. SCM Press Ltd., 1996, 6.

[9]Ibid., pp.6-7.

[10] Ibid., pp.7.

[11]This condemnation shows a negative attitude towards those who are into divination contrasting them with those of what the writers considered a 'true' prophet.

[12] Wilson, R.R. (1987). Early Israelite Prophecy in Interpreting the Prophets. Eds. James Luther Mays \& Paul J. Achtemeier (1987). Fortress Press, U.S.A.1987, p. 6.

[13] Ratzinger, J. The Problem of Christian Prophecy, 1999. Interview by Hvidt, N.C. Retrieved from http://web.archive.org/web/20030114205158/http://tlig.org/ratzfull.html 
their mouth, yet not their own but of God. Since the biblical prophets are essentially God's chosen messengers then their assumption of apostolic work requires tremendous effort and sacrifice.

Being a prophet is a great task and not without great difficulties. ${ }^{14}$ Moreover, there is a great deal in understanding the prophets not only by the message they have but also by their historical context and the manner they have shaped their message. Privost laments that "all that is remembered of Hosea, Micah, Isaiah, Jeremiah and the rest is that they spoke of the Messiah, and there is no thought of the specific historical context of each prophet and the particular coloring which he gave to his message."15 This view is valid since God's chosen watchdogs are historical and situated within a particular realm marked by a specific historical situation people have failed to realize. They cannot be separated from their historical background. Hence, we have to include in our schema the historical condition of the time to conceive a portrait worthy of them as God's prophets.

\section{The Context}

One cannot fully understand the contents and the complex social structure of one's own life or the life of particular society without considering its historical milieu. History plays a crucial role in human affairs as well as in the formation of human condition and thought. This lays the possibility of better understanding not only of ourselves but also "by understanding the forces, choices, and circumstances that brought us to our current situation." $" 16$ This brings to mind the practical role history plays in the direction of mankind. It provides a framework in which we assess or examine our life, in understanding our pursuits, desires, ideals, principles as well as our telos - the "ultimate end of mankind, the end which the spirit sets itself in the world." ${ }^{\prime 7}$ History directs and situates us in a proper context for a purpose. With this in mind, what we have gathered and collected from the texts on the essential roles and characteristics of the prophets are but the by-products of continuing historical examination and reflection. The constructive historical knowledge we have of the prophets is due to our continuing effort to account for their relevance beyond their own time. The hinge of understanding their life is but historical, and not textual. In this manner, deductions are based not only on the connections and relations of ideas or thoughts embedded in the text but also on the historical condition. For instance, Amos' and Hosea's radical opposition and sharp criticism regarding social injustice and moral decay is due to the historical forces of the time driven by the people's selfish desires. ${ }^{18}$ Isaiah's vocal opposition to the plans of the king to be a vassal of an alien nation brings into surface his own

[14] For instance, Amos' possession is perilous (3:8), Hosea realized he was considered a mad man (9:7), Isaiah on the other hand, suffered mocking by his hearers $(5: 19 ; 28: 9)$. See Wolff, Hans Walter, Prophecy from the Eight Through the Fifth Century in Interpreting the Prophets. Eds., James Luther Mays \& Paul J. Achtemeier. Fortress Press, U.S.A. 1987, p.14.

[15] Privost, J. How to Read the Prophets, p.1

[16] Little, Daniel, "Philosophy of History", The Stanford Encyclopedia of Philosophy (Winter 2012 Edition), Edward N. Zalta (ed.), URL = <http://plato.stanford.edu/archives/win2012/entries/history/>.

[17] Hegel, G.W.F. (1857). Lectures on the Philosophy of World History, translated by H.B. Nisbet, Cambridge: Cambridge University Press, 1975. 63.

[18]Amos has a clear target, which is the rich that he condemns for the oppression of the poor. On the other hand, Hosea has no particular target of community but the same condemnation is found. "There is no truth, no love, and no knowledge of God in the land; Swearing and lying, killing and stealing, and committing adultery, they break all bonds, and blood touches blood." Hosea 4:1-2. Hereafter Bible reference is New American Bible (NAB) 
character. ${ }^{19}$ Hosea on the other hand, by employing a quite remarkable metaphor of "marriage" and acute charging of the nation as "harlot" intimates a type of unique character. These characteristics expressed in the text can be deciphered hermeneutically but cannot be taken out of historical context. One salient point to consider is that behavior and attitudes are shaped and reshaped by external forces. Neither Amos, Hosea, Jeremiah, Isaiah, nor Ezekiel could become so dramatically acute, drastic, ferocious, and fearless in their pronouncements and exhortations against the people of Israel and to the powerful elite if they have not seen

Therefore, drawing from historical context the need to fully comprehend a complex view of the prophets' characteristics and the content of their message as well as the embedded technique used in bringing the Word to the world is essential. This same approach in understanding the predicament of the modern period can be understood historically will also be taken up by this paper.

\section{INTERPRETING PROPHETIC MESSAGE: AMOS, HOSEA, ISAIAH, JEREMIAH AND EZEKIEL}

Knowing the life of the prophets, one cannot but appreciate with great wonder how they have overcome great trials and sufferings in the teeth of opposition as well as against the deafness of the people towards God's Word. Their task is sustained by strong faith in God and a unique kind of hope that despite all bitter criticisms and apocalyptic discourses of doom, at the end of their discourse they cannot but still hope for conversion so that salvation through God's infinite mercy and kindness will be given to them. God is working in history and salvation can only be achieved or gained if man has the desire to obtain it. Any struggle requires action. Any judgment by a prophet is a judgment hinging on his spiritual/theological discernment. The prophets and the lives they have lived can be considered as lives in active contemplation. They are always active and engaged and such engagement is public, not private. They were able to disclose themselves to the world, hoping that the world will in turn disclose itself and will hear them. They have exposed their very being and are willing to be harmed if necessary in order to dialogue with the world. However, the disclosure on the part of the world is almost always half-hearted and the engagement is nearly one-sided. The world has not yet disposed to fully reveal itself so that a genuine dialogue and active engagement could take place. This difficulty is seen in the struggle of the prophets to make a good reception of their message by fellow human beings. Their litany of visions, oracles, and poignant images/metaphors seemed to comprise a cacophony. The world has advertently disengaged itself in a quite inimitable discourse for what it hears destroys its hearing. Heschel describes it very well that "The prophet is human, yet he employs notes one octave too high for our ears. He experiences moments that defy our understanding. He is neither 'a singing saint' nor 'a moralizing poet,' but an assaulter of the mind. Often his words begin to burn where conscience ends." 20 This leads us to realize that the primary work of a prophet is to carry the Word despite its sharpness and bitterness. The prophet is ready to open up and is prepared to speak in a language the world can understand. But it is not in mere speaking where the value lies but on the message of the spoken words.

[19] Isaiah fearlessly calls Judah a "sinful nation", "rebellious children", "a people of unclean lips". These scathing remarks are redirected to those who are involved in leadership: elders, princes, and priests.

[20] Heschel, 10. The italicized statement is mine. 
One of the essential characteristics of the prophets is that they are first and foremost men of the Word, of Logos. Such characteristic best defines their mission. Privost argues, "They are people who have spoken, who have come forward, and whose ministry has been devoted to the service of the word." ${ }^{21}$ Jeremiah proclaims, "The word of the Lord came to me: Go cry out this message for Jerusalem to hear!" 22 The Word is like a double-edged sword, which brings happiness and sufferings to the prophets. The logos transform their individuality as well as their being-of-the-world. It gives them happiness and joy when the logos they proclaimed touches the sensibility of the earth and of the community to whom it is directed. It brings suffering and sadness to the prophets when the hearers consider the Word loathsome, hated, despised, and irrelevant. Yet they have to continue fulfilling their mission notwithstanding the difficulty they have experienced. The passion to fulfill their mission is beyond reproach. As Privost describes,

The Word is their sole passion, in both senses of the word. That is, the

Word is what brings them alive, animates them and leads them to commit themselves to transforming the world and changing the future of their people. But it is their passion in the sense that it is the Word that makes them suffer. It is because of the Word that they are persecuted and rejected. ${ }^{23}$

When God chose these people to become his messengers they might have been at first hesitant or reluctant to immediately accept such task for they know the difficulty of the said task yet they have without doubt accept the call. ${ }^{24}$ The prophets therefore had submitted themselves fully to the protection of God. Describing a life of a prophet, Heschel purports, "His [the prophet's] life and soul are at stake in what he says and in what is going to happen to what he says." ${ }^{25}$ This paradox of the Word which both tastes sweet and bitter in turn is best described by Jeremiah and Ezekiel:

When I found your words, I devoured them;

Your words were my joy, the happiness of my heart,

Because I bear your name,

Lord, God of hosts.

I did not sit celebrating

In the circle of merrymakers;

Under the weight of your hand I sat alone

Because you filled me with rage.

Why is my pain continuous?

My wound incurable, refusing to be

Healed?

To me you are like a deceptive brook,

Waters that cannot be relied on! ${ }^{26}$

He said to me: Son of man, eat what you

[21] Op.cit. 8.

[22] Jeremiah 2:1-2

[23] Privost. 8.

[24] Heschel says that "none of the prophets seems enamoured with being a prophet nor proud of his attainment. 17.

[25] Herschel, 6.

[26] Jeremiah 15:16-18 
Find here: eat this scroll, then go, speak to

The house of Israel.

So I opened my mouth, and he gave me

The scroll to eat.

Son of man, he said to me, feed your

stomach and fill your belly with this scroll

I am giving you. I ate it, and it was as

Sweet as honey - in my mouth. ${ }^{27}$

Indeed, the Word that comes from the lips of the prophets is notoriously guileless and scathingly sharp but sometimes kind. The prophets' "tone, rarely sweet and caressing is frequently consoling and disburdening, his words are often slashing, even horrid - designed to shock rather than to edify" 28 is a typical character of a true prophet who is guided by the divine spirit. Jeremiah describes Word as "fire" and the people "wood". 29 From this observation we can say that the prophets who are tasked to bring the Word alive and transform the world into a new one are unorthodox and avant-gardes. They are daring and ruthless with their words and actions. Because of this ruthlessness and contemptuous criticisms, they are stigmatized as madmen by their contemporaries, and, by some modern scholars, as abnormal. ${ }^{30}$ Amos laments, "They hate him who reproves in the gate. They abhor him who speaks the truth." 31 Prophets do not speak of what people want to hear but what they do not want to hear. Their duty is to speak to the people and the powerful "whether they hear or refuse to hear." 32 This tremendous courage made possible because the Word gives them the assurance that what they express and proclaim are of divine origin who upholds truth.

We can say that the prophets are engaged in discursive activity whose task is to shatter the old world and to form and evoke a new world by reshaping public opinion and perception, and cause people to relive their experience. But the shattering and forming of worlds is not done just like as a potter makes clay bowls. It is more similar to how a poet or a painter re-describes the world. In so doing, prophetic speech must stand out, unconventional, unpredictable, or unexpected by the utterer. ${ }^{33}$ They assumed the work of iconoclasts "challenging the apparently holy, revered, and awesome. Beliefs cherished as certainties, institutions endowed with supreme sanctity, he exposes as scandalous pretensions." ${ }^{34}$ The prophets then are imbued with unique ability to speak the Word, shape it, and pronounce it in a quite peculiar and daring way. It is their character to make people scandalized by their utterances, awed by the sublime rhetoric, and left them terribly anxious. This kind of linguistic enterprise is tantamount to committing a primal act of subversion. With such subversive imagination, attitude, and activity is seen in the character of Jeremiah whose words are disquieting, sometimes scandalous, and offensive. Only in a harsh but realistic, vulgar yet simple, honest and brutally frank manner is when they get the attention of Israel.

[27]Ezekiel 3: 1-3

[28] Herschel. p.7.

[29] See Jeremiah 5:14 and Hosea 6:5

[30] Heschel, 18.

[31] Amos 5:10

[32] Op.cit. pp. 19

[33] Bueggemann, W. The Book of Jeremiah: Portrait of the Prophet in Interpreting the Prophets. Eds. James Luther Mays \& Paul J. Achtemeier (1987). Fortress Press, U.S.A. pp. 118

[34] Heschel, 10. 
But we are also reminded that despite the prophets' proclamation of the Word as if it were a "sharp sword, he is not necessarily criticizing organized worship and institutions. His mandate is to counter the misunderstanding and abuse of the Word and the institution by rendering God's vital claim ever present." ${ }^{, 35}$ Here are the words from Jeremiah that sounded blasphemous:

To what purpose does frankincense come to Me from Sheba,

Or sweet cane from a distant land?

Your burnt offerings are not acceptable,

Nor your sacrifices pleasing to Me. ${ }^{36}$

Related to the first essential characteristic of a prophet is their ability to disturb the sensibility of the people. The prophets are good in using a unique linguistic device in bringing to life the words that they proclaim. Aside from being men of vision - a prophet with the penetrating gaze - they, with their words, too, create disturbances to people's consciousness and that of the powerful. While the royal throne is surrounded by great ministers- the "yes-saying" people, the true prophets stand as a sort of "loyal opposition". They hardly believe in the judgment of the rulers. Always the prophets are the adversaries of the king - the "no-saying" individuals. The king employed people to be members of a guild - the great 'yes men', the royal court professional prophets. Outside the palace is where the true prophets lived. The prophets like Amos, Hosea, and Isaiah are good examples of prophets who radically oppose the political policies and decrees of the reigning king, arguing on the basis of divine goodness. But their efforts are to no avail, their words were easily dismissed despite the tragedy this people have experienced, "Neither the words of the prophets nor the experience of disaster seemed to shake the self-reliance of the people of the Northern Kingdom. In pride and arrogance of heart they boasted." ${ }^{37}$ For instance, prophet Hosea is situated in a historical moment when the power of the northern kingdom of Israel is deteriorating. The decline was witnessed by the prophet himself and such event was caused primarily by the untrustworthiness and unfaithfulness of the people to God. ${ }^{38}$ Brown describes Hosea as the "prophet of the decline and fall of the Northern Kingdom, and stood in the same relation to Ephraim in the eighth century as that in which Jeremiah stood to Judah a century and a half later." 39 During this time, the northern kingdom committed political promiscuity that Hosea described as "harlot". This promiscuous affair horrified Hosea, "A vulture is over the house of the Lord!" of God leads to Israel's disastrous end. Hosea spells out the disastrous consequences of trusting in human power or foreign alliances rather than trusting in God, "But you have ploughed wickedness, reaped perversity, and eaten the fruit of falsehood. Because you have trusted in your own power/ and in your many warriors." 41 Just like Amos, Hosea is engaged in a prolonged and sustained condemnation of Israel's religious faithlessness in terms of adultery. Isaiah also grieves:

[35] Ratzinger, J. (1999). The Problem of Christian Prophecy.

See: http://web.archive.org/web/20030114205158/http://tlig.org/ratzfull.html

[36] Jeremiah 6:20

[37] Heschel, 62.

[38] Ibid., 39.

[39]Brown, S.L. (1932). The Book of Hosea. London. pp. xvi

[40] Hosea 8:1

[41] Hosea 10:13 
The bricks have fallen,

But we will build with hewn stones;

The sycamores have been cut down,

But we will put cedars in their place. ${ }^{42}$

Prophet Isaiah fervently called the king to be careful and not to be reckless and gullible regarding his plans of forging an alliance with a more powerful and superior empire. But king Ahaz neglected the admonition by justifying his action as motivated by piety. ${ }^{43}$ The conflict between the prophet and the king is characterized by the obvious difference in worldview and principles. Heschel best underscores the chasm between them:

The gulf was separating prophet and king in their thinking and understanding. What seemed to be a terror to Ahaz was a trifle in Isaiah's eyes. The king, seeking to come to terms with the greatest power in the world, was ready to abandon religious principles in order to court the emperor's favor. The prophet who saw history as the stage for God's work, where kingdoms and empires rise for a time and vanish, perceived a design beyond the mists and shadows of the moment. ${ }^{44}$

In this sense, Isaiah disturbs the sensibility of the king by trying to convince him not to pursue the path he has planning to embrace. However, the king neither listened nor bothered to change his mind. Despite the king's obstinacy towards his plan, the admonitions given by the prophet somehow disturbs the overall vision of the earthly king. The forging of power between Ahaz and Assyria was a success but such success will bring havoc and disaster. Isaiah argued that Assyria would bring disaster. ${ }^{45}$ The same momentous and disparagingly tragic situation happens in the time of Hezekiah who succeeded his father Ahaz.

In general, prophets disturb the people by way of bringing into their senses the issues that they may be aware of but choose to remain blind and silent. If the people can easily resign to silence, the prophets cannot. Prophets cannot simply remain idle amidst these pressing problems. Hence, they were necessarily involved in conflict, which exists between them and the kings, temple authorities, as well as the people themselves. ${ }^{46}$ With outright opposition to the alliances being forged between their nation with the neighbouring powers like Egypt and Assyria. ${ }^{47}$ Critical of the religious practices, prophets severely criticized and denounced religious formalism and triumphalism of the worship since it contradicted the life of injustice and infidelity by the people. They have witnessed the irony and hypocrisy of those people who uphold with great esteem their religious practices and rituals yet were substantially faithless. Prophets have scrutinized and brought into the surface the outright neglect of the people in weighing faith and religious commitment. They may have been too committed to their rituals and the like but such commitment is insufficient in order for one to be considered faithful to God. Despite the people's strict observance of religious life, the people still lacked something essential - faith in God. Because of this, it became deplorable in the eyes of the prophets the faithlessness of the people towards God and their failure to

[42] Isaiah 9:10

[43] Isaiah 7:1-12 "I will not ask, and I will not put the Lord to test." Ahaz said.

[44] Heschel, 66

[45] Isaiah 8:6-8

[46] Privost, 15.

[47] Isaiah 30:1-5 
know the covenant and its demands. ${ }^{48}$ Hosea lambasts the people by declaring, "Hear the word of the Lord, Israelites, for the Lord has a dispute with the inhabitants of the land. There is no fidelity, no loyalty, and no knowledge of God in the land." 49

\section{THE PORTRAITS OF THE PROPHETS}

One of the most important themes their character has revealed to us is their being deeply rooted and connected to the present. They are God's chosen spokesmen grounded in the reality of the present not of the future or of any other time dimension. The prophets are absolutely neither diviners nor futurologists. They are interested first and foremost in the present, "their own present and that of their audience." ${ }^{50}$ Their immediate concern is about the present not the future. What really interests them is changing the present condition that is deplorable. Their oracles speak about the present history of their people. Relating this to our present situation, the oracles may not have the same weight or even depict the current situation of the time but what is important is we are able to make sense of these oracles and find significant connection to our present condition. In the words of Privost, "it is not enough to repeat the oracles of the prophets of the past. These oracles require to be meditated on assimilated and then adapted to meet the needs of the moment." ${ }^{, 51}$ The point is very clear. Despite the great gap between two different "presents", the connection still remains intact. This connection is maintained by the eternal wisdom hidden in the oracles of the past prophets. The text gains new life every now and then. Perhaps it may not only be their insights that have been secured in the text over time that is relevant but the prophets themselves too. "They speak out of our age but to it, because the Word of God is in their mouth." ${ }^{, 52}$ Scott said:

The remarkable contemporaneousness of these ascent spokesmen of religion and the perennial freshness of their message, spring from their power to penetrate past the maze of appearances to underlying human and religious facts stated in universal terms, but with notable concreteness. ${ }^{53}$

Similar to this notion is what Isaiah proclaims, "The Egyptians are human beings, not God, their horses flesh, not spirit; When the Lord stretches forth his hand, the helper shall stumble, the one helped shall fall, and both of them shall perish together." 54 This concreteness of the prophets' utterances cannot be denied for what they say should not only be heard but understood. Both their thought and personhood is relevant in the present. What they have spoken in their time, their unequivocal judgments are rooted in the presence of the present moment is applicable today. Although of different historical contexts, in the eyes of God, difference is but eternity. Seen in God's view, all struggles confined in a particular historical horizon have no singular difference to God. Difference lies in the mind of the finite beings.

Considering this character of the prophets, we have added another figure that would complete the "portrait". Corollary to our belief that the prophets are men of the present, their

[48] Privost.. 16.

[49] Hosea 4:1

[50] Privost, pp. 9

[51] Ibid.. 10.

[52] Scott, R.B.Y. (1968). The Relevance of the Prophets: An Introduction to the Old Testament Prophets and their Message. London: MacMillan Company.

[53] Ibid.. 217.

[54] Isaiah 31:3 
observation is indispensable - that is, they cannot escape within their visual field the moral condition of their time. Almost all Major Prophets if not so explicit, implicitly articulated their disgust towards the ominous shattering of morality. There is a "vehement denunciation" 55 of the moral putrefaction and social injustice shadowing the entire nation. Amos for one was so critical about the sins of the nation. He almost criticized everyone, the middle class, the governing body, the priesthood, the establishments, and the king himself because they were all inundated by a superficial kind of pietism. Heschel observes "The prophets consistently singled out the leaders, the kings, the princes, the false prophets, and the priest as the ones responsible for the sins of the community." ${ }^{56}$ For Amos, lack of moral discernment and proper use of reason contradicts as well as destroy the connection between theory and practice. Being just and good to God must also be rendered to fellow human beings. This principle fails to be realized by the people of Israel. While glamorous, pompous, and extravagant festivities were offered to God, Israel's poor and needy were neglected and deprived. This leads Amos to denounce the wealthy, the powerful and the way these people treated the marginalized. To illustrate this dramatic rhetoric by Amos, some passages are worth reading:

Hear this word, you cows of Bashan, who live on the mount of Samaria: Who oppress the destitute and abuse the needy; who say to your husbands, "Bring us a drink!" The Lord God has sworn by his holiness: Truly days are coming upon you when they shall drag you away with ropes, your children with fishhooks; You shall go out through the breached walls one in front of the other, And you shall be exiled to Harmon - oracle of the Lord. ${ }^{57}$

There is a wonderful pun here. The wealthy women of Samaria are referred to as cows of Bashan. Bashan is considered as a very rich pastureland and also such name is very common to refer to the nobility, and even to gods, with terms like bull or ram or cow. The words may seem revolting and insulting but were not. Amos, when he refers to the cows of Bashan, it is a flattery. Yet the pun is quite fantastic because these women more or less are going to end up like fat cows, as slabs of meat in the butcher's basket. What a horrendous end.

Another scathing attack on the idle life of the carefree rich who ignore the plight of the poor can be notably seen in the following passage.

Woe to those who are complacent in Zion, secure on the mount of Samaria, Leaders of the first among nations, to whom the people of Israel turn... Those who lie on beds of ivory, and lounge upon their couches; Eating lambs taken from the flock, and calves from the stall; Who improvise to the music of the harp, composing on musical instruments like David, who drink wine from bowls, and anoint themselves with the best oils, but are not made ill by the collapse of Joseph; Therefore, now they shall be the first to go into exile, and the carousing of those who lounged shall cease. ${ }^{58}$

No wonder why Amos unhesitatingly spews such heavy and derisive comments against the elite class - the oppressors par excellence. While the powerful are enjoying the pleasure that

[55] Kaufman, Y. (1972). The Religion of Israel. Trans. Moshe Greenberg. New York: Schocken Books. 347.

[56] Heschel, 203. Also see Hosea 5:1 and Isaiah 3:14-15

[57] Amos 4:1-3

[58] Amos 6:1, 4-7 
their wealth has brought them and indulging them in extravagant lifestyle, the people below the ones who sacrifice and suffer from oppression and abuse were left miserable and hopeless. Due to moral decay, greediness, and the indulgence of the elite class, this causes social injustice that for Amos shocks and outrages God.

Hear this, you who trample upon the needy and destroy the poor of the land; 'When will the new moon be over,' you ask, 'that we may sell our grain, and the Sabbath, that we may open the grain-bins? We will diminish the ephah, add to the shekel, and fix our scales for cheating! We will buy the destitute for silver, and the poor for a pair of sandals; even the worthless grain we will sell! $!^{59}$

What is clear in this series of scathing attacks by Amos and the denunciation of such moral indecency is the relevance and the prevalence of the same crimes committed today. The crimes that are denounced as utterly objectionable to God and infuriated God are kind of crimes we see around us every day. Moral decay and social injustice remain a problem of our time. Graft and corruption, bribery, extortion, lack of sympathy and charity to the poor, and indifference to the plight of the sufferings are just few among many things that contribute to the degradation of our morality as well as keeping social injustice a useful tool for the elite.

In the eyes of the prophets, social injustice is a severe result of the perversion of justice. 60 "When warped and garbled, justice yields strife and distrust" 61 says Heschel. Hosea provides a good description: "They utter mere words; with empty oaths they make covenant; so judgment springs up like poisonous weeds; in the furrows of the field." 62 Indeed, the shepherds are "stupid" according to Jeremiah and "Thus says the Lord God: Behold, I am against the shepherds; I will require my sheep at their hand" uttered Ezekiel. ${ }^{63}$ What is then common during their time is the presence of injustice. What is scarce is justice. Modern thinkers may have a very simple meaning of what justice is - that is giving what is due to a person who ought to receive what he ought to receive. It can also be understood in light of trying to escape or avoid a tendency to commit injustice, which means an "active process of remedying or preventing what should arouse the sense of injustice." ${ }^{64}$ But in the minds of the prophets, their view of justice is in relation to the absence or the presence of oppression and corruption. This means justice abounds when there is an absence of negative values while injustice is the presence of the said negative values. This conceptual view, though simple yet rooted in the reality of the world where the prophets have lived. They see things in concrete way and express what they have seen or observed in same manner.

What can we say about the portrait of the prophets? There could be a lot more of possible entries to form a good picture of the prophets but what we have here are relevant to the task. This particular portrait of the prophets guides us in our critique of the post-secular society. Since what we have discovered upon the examination of particular moments in the historical lives of the prophets as well as in bringing to the surface the architectonic of their oracles, visions, and exhortations are organic ideas and insights as a result of historical

[59] Amos 8:4-6

[60] Heschel, 202.

[61] Ibid. 202.

[62] Hosea 10:4

[63] Jeremiah 10:21, Ezekiel 34:10

[64] Cahn, E.N. (1949). The Sense of Injustice. New York. 13. 
movements. The prophets as we have said are bearers of logos, unorthodox - avant-gardes par excellence, acute defenders of morality and denouncers of injustices, emphatic advocates of the well-being of the poor and the oppressed, and not to forget their unconditional love and trust to God. Having this in mind, we have a portrait of a prophet who is deeply rooted in the love of God, to his own social context, who is aware of the oppressive and unjust forces operating around him, who is not afraid to publicly articulate and denounce such sinister forces ${ }^{65}$ even it gravely disturbs the people, and exquisitely use God's Word to soften the hardened hearts of the notables and the entire people of Israel.

\section{THE PROPHETIC PARADIGM: ON HOW TO INTERPRET THE POST-SECULAR SOCIETY}

How are we to make sense of the prophetic portrait paradigm? There are three important points to consider: first, the present social condition and the eternal recurrence of the human predicament - overcoming one's network of idiosyncrasies developed by the highly secularized society; secondly, the locus of the new prophet is scattered within the web of human relationships and interactions; thirdly, in the age of highly secularized, relativistic, groundless, and decentralized society, difficulty in articulating the cause of decadence in religious worldview arises. Going back to the prophets is a good start. This I do not mean that only through the prophetic tradition one can only profoundly articulate the social condition of the present in religious terms but just simply trying to underscore the depth of the contribution of prophetic tradition in the life of the Church.

Cardinal Joseph Ratzinger in one of his lectures criticized the modern attitude of men who are rabid adherents of reason as well as the belief that reason is the sole arbiter and determinant of knowing good and truth. This attitude is seen in a deliberate removal of the term "God" in the preamble of the European Union. This type of behaviour is symptomatic of a highly secularized world where religious actuations and language are irrelevant in forming public reason. ${ }^{66}$ But Ratzinger is quick to remind us that:

Even the rejection of the reference to God, is not the expression of a tolerance that desires to protect the non-theistic religions and the dignity of atheists and agnostics, but rather the expression of a conscience that would like to see God cancelled definitively from the public life of humanity, and relegated to the subjective realm of residual cultures of the past. ${ }^{67}$

He strongly asserts and reminds us that what "characterizes today's world is not between various religious cultures, but that between the radical emancipation of man from God."68 This response from an ultra-conservative defender of the Catholic tradition and faith is directed to those who considered God remains a hypothesis impossible to be proven by natural science. Moreover, the secularization thesis reverses the values with religious import by taking away the unnecessary elements of religious importance. When Friedrich Nietzsche

[65] Demeterio, F.P.A. (2012). Antonio Gramsci and Edward Said's Image of a Modern Day Intellectual and the Filipino Roman Catholic Priest. Volume 23 No. 2. Lumina. Bohol, Philippines

[66] Richard Rorty in one of his books raised the issue about the value of religious talk in public sphere by asking if religion is a conversation-stopper or not? Rorty responded in affirmative. However, Habermas in his later works recognizes the importance of religious tradition and total abnegation of which is a sweeping generalization.

[67] Ratzinger, J. (2005). Meaning and Limits of the Present Rationalist Culture. Retrieved Feb 28, 2014 from http://web.archive.org/web/20061002191500/http://www.zenit.org/english/visualizza.phtml?sid=74826

[68] Ibid. 
declares that "God is dead", modernity embraces a new and unfamiliar terrain which morals are merely reduced to subjective feelings and emotions. This modern disposition also changes the tenor of the human mode of identity, meaning, and struggle. So much so that such paradigmatic shift from the traditional views of human existence to a more liberal acceptance of unstable and unsecured human destiny is without hesitation uphold by secular men. There is a deafening and awkward silence of the religious as the world clinches tight to secular values. However, within these historical moments of the present time, intermittent dialogue with religion by the secular society produces little progress. Even such progress is so little it creates holes and gaps, which allows the possibility of continuing dialogue with religion for inclusivity in forming public reason.

As the society tries to distance itself from the religious influence, it also situates people in a position where s/he finds no focus and whose values no longer sustain him in various aspects of his personal struggles and search for meaningfulness of life. As the world becomes highly individualized and decentralized the more it needs guidance not from itself but from the outside. The secularized society proves that it can self-regulate, able to sustain itself from disastrous anomalies and repair itself eventually. However this is no longer the case today. The secular society has to admit its shortcomings and should renew itself by welcoming outside force.

Either secularization or de-secularization, the world becomes a place where danger is eminent. Living dangerously becomes part of human consciousness everyone has to emphatically accept. The rise of polymorphous agencies and institutions that promote abuse and oppression continues as the new kings in the form of capitalism, relativism, indifference, lack of empathy, and apparatuses of power greatly affect and destroy the arteries of human organisms. In recent years intermittent uprisings and revolutions in most of the Arab countries exemplify the discontent and intense infuriation of people against those in power the highly respected but corrupt notables.

God no longer works in a history of a particular nation or country. He is now working and actively participating in the history of mankind. God's Israel in no longer a particular civilization or ethnic group but is the conglomeration of different civilizations. Total annihilation or destruction of one civilization after another is not a matter of choice or preference by God but rather an outcome of man's failure to recognize in his present mental and conscious state that God participates and involves in the making of history. Taking cue from the prophets, condemnation and termination of lives is inevitable likewise hope.

The depressing human life presents us how deplorable and pitiful we are as human beings. Relying on our own potentials for clearing out our deficiencies and shortcomings are not enough in making our lives meaningful. Self-creation no longer provides interesting motifs to transcend the transitoriness of our being as well as the inherent anxiety of human existence. More is needed and required for us. It is high time for God to return to the center.

\section{CONCLUSION}

Who are the present prophets? Does the prophetic portrait as a paradigm of critique helps us understand and reflect the present social condition? What about "prophetic integration" of ideals, principles, and norms? In the above discussion, it has argued that a prophet based on the essential characteristics we have identified is first and foremost a man of the Word, someone who disturbs people, and denounces moral evil and social injustices. A prophet is deeply rooted in God's love, and who is well aware of the oppressive and 
injustice forces around him, always situated and connected to the present reality as well as someone who is not afraid to articulate the pressing problems and issues of his time despite of danger he will face. With this kind of portrait, we can examine in-depth the issues and problems hidden beneath the intricate structures, apparatuses, and dynamics of our society today. Prophetic integration is important for the formation of human beings to become better persons of the post-secular society. The need for the return of the prophets as well as the reassumption of God to be in the centre is indispensable to sustain mankind and avoid God's wrath due to contemptuous and unacceptable human actions.

\section{REFERENCES}

[1] Bueggemann, W. The Book of Jeremiah: Portrait of the Prophet in Interpreting the Prophets. Eds. James Luther Mays \& Paul J. Achtemeier (1987). Fortress Press, U.S.A. pp. 118

[2] Demeterio, F.P.A. Antonio Gramsci and Edward Said's Image of a Modern Day Intellectual and the Filipino Roman Catholic Priest. Volume 23 No. 2. Lumina. Bohol, Philippines, 2012.

[3] Hegel, G.W.F. (Lectures on the Philosophy of World History, translated by H.B. Nisbet, Cambridge: Cambridge University Press, 1975. 63.

[4] Kaufman, Y.. The Religion of Israel. Trans. Moshe Greenberg. New York: Schocken Books. 1972.

[5] Little, Daniel, "Philosophy of History", The Stanford Encyclopedia of Philosophy (Winter 2012 Edition), Edward N. Zalta (ed.), URL = <http://plato.stanford.edu/archives/win2012/entries/history/>.

[6] Privost, Jean-Pierre (1996). How to Read the Prophets. Translated Bowden, J. SCM Press Ltd.

[7] Ratzinger, J. (1999). The Problem of Christian Prophecy. Interview by Hvidt, N.C. Retrieved from http://web.archive.org/web/20030114205158/http://tlig.org/ratzfull.html

[8] Ratzinger, J. (2005). Meaning and Limits of the Present Rationalist Culture. Retrieved Feb 28, 2014 from http://web.archive.org/web/20061002191500/http:/www.zenit.org/english/visualizza.phtml?sid=74826 [9] Scott, R.B.Y. (1968). The Relevance of the Prophets: An Introduction to the Old Testament Prophets and their Message. London: MacMillan Company.

[10] Wilson, R.R. (1987). Early Israelite Prophecy in Interpreting the Prophets. Eds. James Luther Mays \& Paul J. Achtemeier (1987). Fortress Press, U.S.A. 6.

[11] Wolff, Hans Walter (1987). Prophecy from the Eight Through the Fifth Century in Interpreting the Prophets. Eds., James Luther Mays \& Paul J. Achtemeier. Fortress Press, U.S.A, 1987. 